\title{
LUTSI SPEAKERS AND REMEMBERERS IN THE LATE 20TH AND EARLY 21ST CENTURIES
}

\author{
Uldis Balodis \\ University of Latvia Livonian Institute, $L V$ \\ Western Institute for Endangered Language Documentation, US \\ ubalodis@lu.lv
}

\begin{abstract}
This article describes the language of the last speakers of Lutsi as well as their family background and the sources of their language knowledge, in order to show the paths by which Lutsi language knowledge - even if only of a fragmentary sort has survived up to the present day. The language knowledge of these last speakers is described using observations taken from the field notes and memories of other researchers as well as from my own encounters with them. This information is placed in a historical and regional context by providing a detailed overview of the historical extent of the Lutsi community, theories about Lutsi origins and how this connects with the memory of Lutsi families and observed language variation within the Lutsi speech area, changes in Lutsi speaker numbers and language use, and the history of Lutsi documentation and the observations of the researchers who documented them.
\end{abstract}

Keywords: endangered languages, language islands, language extinction, rememberers, Latgale, Finnic languages, South Estonian, Lutsi

DOI: https://doi.org/10.12697/jeful.2021.12.2.09

\section{Introduction}

Lutsi is a variety of South Estonian, which developed in relative isolation from the main body of South Estonian speakers in Estonia for several centuries and was historically spoken in several dozen villages in the countryside surrounding the town of Ludza in eastern Latvia (Latgale) (Vaba 1997, Pajusalu 2008). The first mentions of Estonians living in this area date to the mid-19th century (Brandt 1845, Manteuffel 1869) and the first major expedition to describe the language, culture, and origins of this community was conducted by Estonian researcher Oskar Kallas in 1893. Lutsi continued to be documented at intervals throughout the 20th century. The Lutsi community assimilated 
linguistically into the Latgalian, Latvian, and Russian speech communities and ceased to be used as a language of occasional daily interaction in the 1970s and 1980s. However, following the death of the last fluent speakers during this period, Lutsi continued to live on in the last partial speakers through the early 21 st century and those who only remembered fragments of the language of their ancestors.

This article describes the language of these last speakers as well as their family background and the sources of their language knowledge, in order to show the paths by which Lutsi language knowledge - even if only of a fragmentary sort - has survived up to the present day. The language knowledge of these last speakers is described using observations taken from the field notes and memories of other researchers as well as from my own encounters with them.

In their article on the structural consequences of language death, Campbell and Muntzel (1989: 181) categorise language proficiency using the following model: "S for "strong" or "(nearly) fully competent"; $I$ for "imperfect", i.e. for reasonably fluent so-called "semispeakers"; $W$ "weak semi-speakers" with more restricted speaking competence...; and $R$ for so-called "rememberers" who know only few words or isolated phrases". This model is adopted in the present study in order to draw a distinction between fluent/partial speakers and rememberers - those who still possess some memory of Lutsi in the Lutsi descendant community.

Sections 2-5 place Lutsi in its historical and regional context by describing the location where it was spoken and its historical extent over this region (Section 2), theories about the origins of the Lutsis and how this connects with the memory of Lutsi families as well as language variation within the Lutsi speech area (Section 3), changes in speaker numbers and language use (Section 4), and the history of documentation of the Lutsis and their language (Section 5). Sections 6-7 describe the language knowledge and histories of the last known family where Lutsi was spoken (Section 6) and the rememberers whom I have met and interviewed (Section 7). Section 8 discusses some of the features of the Lutsi rememberers' language and compares the Lutsi fragments discussed in this article to the fragments documented from Krevin Votic rememberers in the 19th and 20th centuries. 


\section{Location}

Lutsi was historically spoken in several dozen villages across a wide area north, south, and southeast of the town of Ludza in the Latgale region of eastern Latvia. In his monograph Lutsi maarahvas (Ludza Estonians), Kallas (1894: 13-15) lists 53 villages, which he describes as follows: "Some of the villages listed are now completely Latvian but 40 years ago were Estonian; in others, Estonians and Latvians have always lived mixed. I list all the villages where there are still Estonians and also those where according to popular accounts they had once been." (Kallas 1894: 12).

There certainly were also other communities in this region where Lutsis have lived in the past. Some communities such as Mytsa külä ${ }^{1}$ (Latvian: Germi) - which has a historical connection with the Lutsis (Kallas 1894: 16) - and Dülüni (possibly Latvian Dilāni in Kaunata parish) - the village where Kallas's consultant Rōza Gudrenik lived (Kallas 1894: 78) are mentioned already in Lutsi maarahvas. Researcher Paulopriit Voolaine also recorded 10 folk songs from a Lutsi speaker in Mytsa külä in 1925 (Voolaine 1925-1926). Later researchers have also noted other communities where Lutsis have lived (Voolaine 1925, 1926a, Korjus 2004) or may have lived (Balodis 2019). Ultimately, this is also a question of how one defines a Lutsi community - is this any community where a Lutsi person has ever lived or must it meet other criteria? However, Kallas's list of 53 villages gives a good idea of the historical range of Lutsi habitation. These villages and other communities significant to the Lutsis are shown on the map in Figure 1. Every village and place mentioned in this article is also labelled on this map.

The administrative boundaries shown on the map reflect borders as of summer 2021. All Lutsi villages are located within the new larger Ludza municipality (Latvian: Ludzas novads) formed on 1 July 2021 following the reform of Latvia's administrative divisions this year. The majority of Lutsi documentation refers to parish boundaries as they existed during Latvia's interwar independence (these boundaries existed until 1949), which differ from those shown on this map. This practice is

1 Unless otherwise noted, the Lutsi practical orthography described in Balodis (2015, 2020 ) is used for Lutsi place names, personal names, and other uses in this article. 
also followed in this article. The cluster of villages to the south of Ludza corresponds to those located in pre-1949 Pilda parish, the cluster to the southeast of Ludza is located almost entirely in pre-1949 Nirza parish with a few eastern villages in pre-1949 Brigi parish, and the cluster north of Ludza is located in pre-1949 Mērdzene parish.

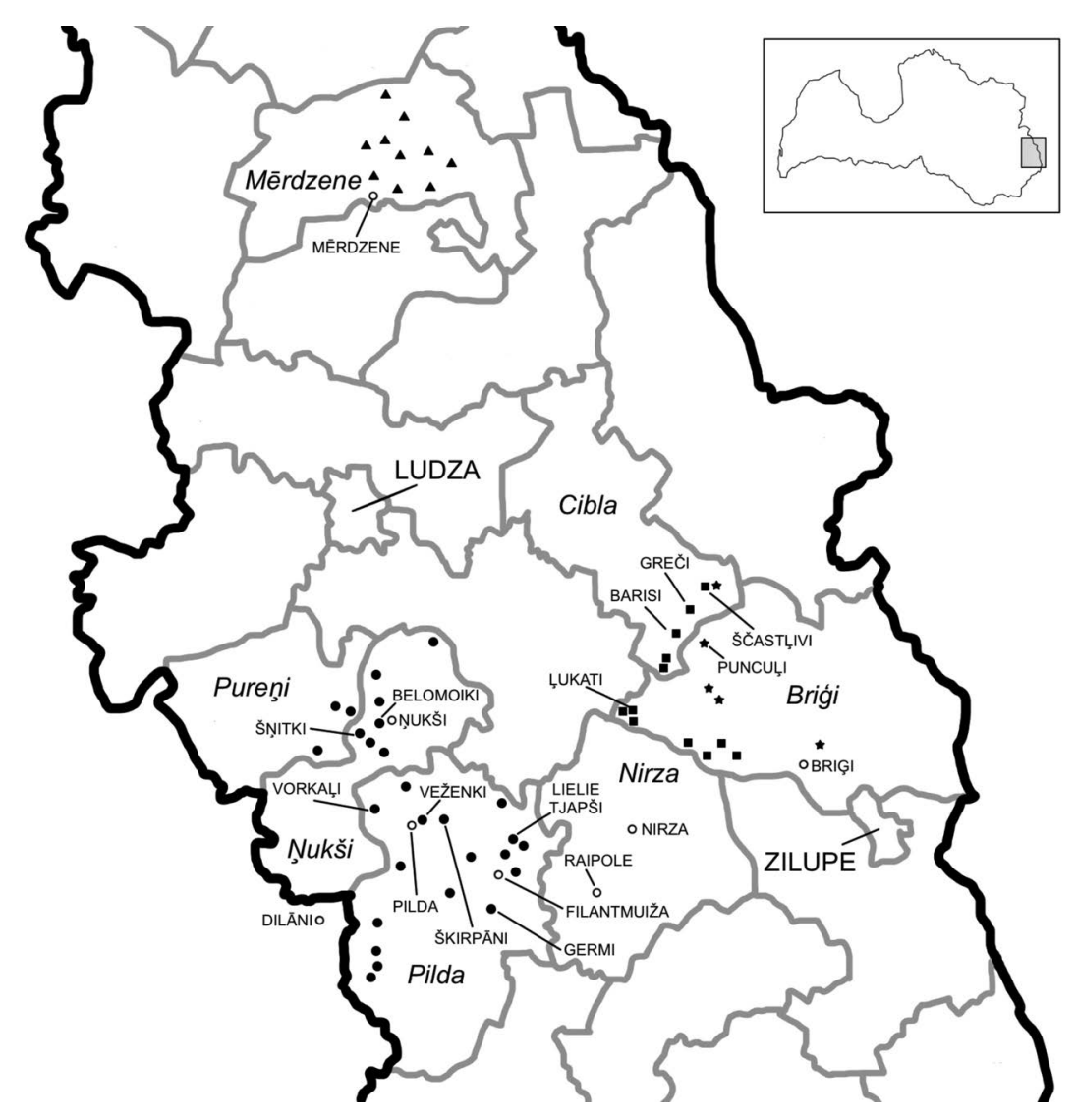

Figure 1. Lutsi villages (identified according to their location in the pre-1949 parishes: $P$ ilda $=$ solid circles, Nirza $=$ squares, Briği $=$ stars, Mērdzene=triangles) with other communities of note (open circles) within modern (as of July 2021) administrative divisions (names in italics). 


\section{Origins}

The origin of the Lutsis is not clearly known and they have given researchers various accounts. In the earliest accounts, recorded by Mihkel Veske and Oskar Kallas, the Lutsis stated that their ancestors had come from Sweden or from the Swedish king's land (Weske 1877, Kallas 1894), i.e., Estonia during the period of Swedish rule (16291721) and from Rìga land (Weske 1877), i.e., the province of Livonia. For example, Kallas (1894: 37) records this account from a 50-yearold man in Pilda parish: "My grandfather's father Jakap came together with his brother from Sweden [i.e., Estonia], from Vähä village and arrived here also in Vähä village [=Latvian: Veženki]." (Me vanaezä ezä, Jakap, tul'l' vellega ütehn Rood'i maalt Vähä küläst, ja siie sai ka Vähä külä.) This quote also highlights the fact that some Lutsi villages have names in common with villages in southeastern Estonia (see e.g., Ojansuu 1912: 21 for a comparison of similar/identical village names near Ludza and near Vastseliina in Estonia) indicating a possible place of origin for a portion of the Lutsis.

Other origin stories have mentioned Lutsi ancestors fleeing a war, which is understood as referring to the Great Northern War, or coming to Catholic Latgale to avoid forced conversion to Lutheranism (for more see Balodis 2020). For an example of a story mentioning this war, see "Eestlastest Lutsimaal" (About the Estonians of the Ludza region) told by Osips Jakimenko of Škirpāni village (Lutsi: Kirbu külä) in Pilda parish in 1960 (Mets et al. 2014: 213-215). Other more prosaic reasons are also mentioned such as Estonian peasants being purchased by a local manor lord in exchange for goats (Pence 1972: 123).

In the course of my field work in the Ludza region between 2013 and 2017, several Lutsi descendants have also shown me 19th century land deeds for family properties in Lutsi villages or told me that their families purchased their land during that time, which could mean that their ancestors arrived in the 19th century or, alternatively, were already living near Ludza then and purchased land in those areas at that time.

Most families I have interviewed do not have a specific ancestor they can identify as coming from Estonia, but instead are just aware of having Estonian roots and/or Estonian-speaking (i.e., Lutsi-speaking) ancestors. However, one such case does appear in a family tree documented in a school research study undertaken by Ginta Birska in 
2009. She notes that in the family tree of Antons Buls of Barisi village (Lutsi: Mägize külä) in Nirza parish, the oldest known male ancestor Kazimirs Buḷ - married a woman from Estonia named Ilze (Birska 2009: 23). This could point again to a possible time of origin for a portion of the Lutsi community or, alternatively, to ongoing sporadic contacts with Estonia also seen in the Kraasna language island (see Kallas 1903, Weber 2021) where manor lords owning properties in Kraasna and southeastern Estonia would bring women and men from Estonia as potential marriage partners for young people in the Kraasna community. Birth years for Kazimirs and Ilze Buḷ are not included in the family tree given in the appendix of Birska's study. However, their oldest child, Andris Bulis, is shown as having been born in 1842; extrapolating from this, Kazimirs and Ilze may have been born around 1820 or earlier.

The abundance of origin stories and lack of any known single founding event for the Lutsi community in the historical record suggests that the Lutsi language island formed as a result of several different population movements of differing sizes and due to various reasons over at least the last three to four centuries. This theory is also supported by variation seen in the language spoken by the Lutsis. Lutsi is not uniform and shows some of the same variation as subdialects in southeastern Estonia and adjacent areas such as variation in the inessive case ending. In the west in Pilda parish, the inessive ending $-h$ is more prevalent, while in other parts of the Lutsi-speaking region, $-n$ is more prevalent (Balodis, forthcoming). This division also exists in South Estonian subdialects in Estonia; however, there the opposite distribution is observed - the inessive ending $-n$ is more prevalent in the west, while - $h$ is more prevalent in the east (Iva 2007: 24). The existence of this same variation in specific parts of the Lutsi-speaking region - rather than use of only one ending or a mixture of all endings - may point to the Pilda parish Lutsis originating from a population in the eastern part of the South Estonian speech area in Estonia where the $-h$ inessive is more prevalent and the Nirza parish Lutsis originating from the western part of this area where the $-n$ inessive is more prevalent. The $-n$ inessive characteristic of Nirza parish is also found in one of the remembered Lutsi fragments discussed in this article (see (2)). Leontīne Antonovathe rememberer who recalled this fragment - was originally from Greči (Lutsi: Grēki) in interwar Nirza parish. 


\section{Speakers and population}

As noted above, at present, the Lutsi descendant community is fully assimilated into the surrounding speech communities. In my conversations with Lutsi descendants, most consider themselves Latvians and/or Latgalians with Estonian ancestors, though at least one Lutsi descendant I have met - Bronislava Zambere - identified as Estonian (see Section 7). In broad terms, the grandparents or great-grandparents of currently middle-aged or older Lutsi descendants will have been the last generation in their families to have spoken Lutsi fluently.

The total number of Lutsi descendants is difficult to estimate. However, it likely numbers in the thousands in Latvia and also among the Latvian diaspora and their descendants living outside of Latvia. Two common last names associated with the Lutsis are Buls (and its variants: Buḷs, Bulis, Buḷis) and Mekšs. According to the 2011 Latvian National Census, a total of 1627 people $^{2}$ had one of these two last names in Latvia. This likely only scratches the surface of the number of people with Lutsi ancestry alive today, but does provide a baseline figure for such estimates.

There has never been a formal census of Lutsi speakers, though researchers have made estimates of the speech community's size, which are shown in Table 1. See Section 5 for English translations of a few short quotes from these researchers, which provide context for the language situation they encountered as well as how they defined a Lutsi speaker for their count.

The figures for 2013 and 2021 are based on my own assessments since I began researching the Lutsi community in 2013. The number of rememberers in 2013 and 2021 may be higher than shown, as there may be rememberers I have not found. The difference in the number of rememberers between these two years reflects the loss of those who passed away in the interim. Also, rememberers only include those who have inherited knowledge within their families or close community, rather than learned words by some other means (e.g., from a book or school activity).

2 The specific 2011 census figures for the number of people with these last names, which I obtained through an inquiry to the Central Statistical Bureau of Latvia (Centrālā statistikas pārvalde) are: Bula (284 people), Bule (414), Bulis (104), Buls (350), Buḷa/Buḷe (64), Buḷs (150), Mekša (154), Mekšs (107). 
Table 1. Estimates of Lutsi speakers.

\begin{tabular}{l|l|l}
\hline Year & Estimated number of speakers & Source \\
\hline $\mathbf{1 8 9 3}$ & 800 & Kallas 1894 \\
\hline $\mathbf{1 9 1 2}$ & 200 & Ojansuu 1912 \\
\hline $\mathbf{1 9 2 5}$ & 120 & Voolaine 1925 \\
\hline $\mathbf{1 9 3 6}$ & 200 & Sang 1936a \\
\hline $\mathbf{2 0 0 1}$ & 2 & Korjus 2002 \\
\hline $\mathbf{2 0 1 3}$ & 1 partial speaker, $\geq$ 7 rememberers & Balodis \\
\hline $\mathbf{2 0 2 1}$ & 0 speakers, $\geq$ 4 rememberers & Balodis \\
\hline
\end{tabular}

\section{History of documentation}

This section describes the changes in Lutsi language knowledge and use in the words of the researchers who studied the Lutsi community from the late 19th to the early 21 st centuries. These quotes are translated by me from Estonian (Kallas 1894, Voolaine 1925, Sang 1936a), Finnish (Ojansuu 1912), and Latvian (Korjus 2002).

As noted above, the first extensive documentation of the Lutsis was carried out by Oskar Kallas (1868-1946). Kallas documented Lutsi across the large region encompassing its historical speech area. His language documentation consists primarily of folk songs and proverbs and he is the only researcher to document the South Estonian spoken in Merrdzene parish. He notes that he found only two women in the parish who could still sing songs in Estonian (1894: 75); nevertheless, this provides the only information available on the language spoken in this part of the Lutsi speech area. Kallas characterised the situation he encountered during his research as follows:

"Perhaps it could be said that there are still about 800 Estonian speakers, with those who can understand with difficulty included in this 800 . The language is partly lost, partly disappearing, it has been or is being replaced by Latvian, Latvian and Russian, rarely just Russian. Often all three languages are mixed up; I know a man who speaks Estonian with his 82-year-old father, speaks Latvian with his Latvian wife, his children who attend Russian school speak Russian with their parents; in church the man prays from a Polish prayer book. When children today have reached this man's age, then Estonian will hardly be heard anywhere, only in a few places [like] Filantmuiža village; other villages will then be as far gone as [Mērdzene] parish is now." (Kallas 1894: 17) 
The next major documentation of Lutsi came in 1911 and was conducted by Heikki Ojansuu (1873-1923) who focused his attention on the villages of Pilda parish and left over two hundred pages of handwritten documentation consisting of vocabulary, songs, stories, and other stretches of transcribed connected speech. Ojansuu was the only researcher to document the language of several villages in Pilda parish including Belomoiki and Šnitki. After Ojansuu, no documentation exists from any other villages aside from Lielie Tjapši, Škirpāni, and Germi in Pilda parish; Greči, Ščastl̦ivi, and Barisi in Nirza parish; and Puncul̦i in Brigi parish. Ojansuu describes the language situation during his expedition as follows:

"Kallas estimated the number of Estonian speakers in the Lutsi region at approximately 800; presently, there are hardly more than 200; Latvianisation is proceeding quite quickly. While Kallas still heard children speaking Estonian in some villages as they played on the village roads, I found only a few people under the age of 20 who could understand Estonian, and only in that same (Škirpāni) village.” (Ojansuu 1912: 18)

During Latvia's interwar independence, the two primary researchers of Lutsi were Paulopriit Voolaine (1899-1985) and August Sang (1914-1969). Paulopriit Voolaine's work extended for a significantly longer period than Sang's and also involved attempts at strengthening the position and encouraging knowledge of Lutsi within the Lutsi community. Voolaine wrote several unpublished studies on Lutsi phonology (Voolaine 1927) and morphology (Voolaine 1926b). He also documented ${ }^{3}$ the only known examples of Lutsi language from Germi10 folk songs recorded from Jān Herman (Voolaine 1925-1926) - and the only examples of Lutsi from Brigi parish recorded after Kallas's 1893 expedition - a folk song from Pītre Fomīn and a sentence from Elizabet Fomīn in Puncuḷi (Lutsi: Puntsuli) (Voolaine 1925-1927).

3 Voolaine's materials are available at AEDFUL. His phonology study is indexed as AES0180, his morphology study as AES0130. Handwritten copies of the originals are available as PDFs online at AEDKL (see bibliography for links). Voolaine's manuscript containing the folk songs from Germi is indexed as ESMT0102 and and the manuscript containing the song and sentence from Puncuḷi is indexed as ESMT0022 and are available online at AEDFUL. 
Voolaine worked with the Lutsis to open Estonian schools in Pilda and Nirza parishes; an effort which was, however, ultimately unsuccessful (for more see Korjus 2021). During the Soviet years, Voolaine returned and would also help lead expeditions by other Estonian linguists and researchers to the Lutsi communities and to document their language. For the rest of his life, Voolaine maintained close ties with the Nikonovs family in Lielie Tjapši, which included the last speakers of Lutsi (for more on this family see Section 6). Voolaine's (1925: 373374) description of the language situation in the early years of his work is given below. Note that Latvian names for villages are rewritten in their standard Latvian form or replaced using brackets. Voolaine uses Estonian phonetic approximations for these names in the original (e.g., Škirpaanõ instead of Škirpāni).:

"In [Mērdzene] parish...[people] know how to say just a few words in Estonian. In [Pilda] parish, [one] can speak with about 60 people in Lutsi. In Kirbu (Škirpāni) village... [one] can speak with 23 people; in [Lielie Tjapši] Suurõ Tsäpsi (Jaani village...) - [one] can converse with 16 people. In other villages, $0-5$ people know how to speak Lutsi. In Nerza parish, they can speak Lutsi: almost 20 people in Tati (Ščasțlivi) village...; about 30 people in Greeki (Greči) village...; 15 people in Mägize (Barisi) village... In the other villages, just a few speak Lutsi... In [Brigi] parish, [one] can converse with barely 10 people in Lutsi. Even in Puncuḷi village...only 4-5 people can understand Lutsi... Lutsi speakers are people aged 50-90 who are called: maamiis, igauns, tšuhhna, suur tśuuhna. Only in [Lielie Tjapši] - to the amazement of the people of the village - does 3-year-old Oodum Jerašenko understand Lutsi." (Voolaine 1925: 373-374)

August Sang accompanied Paul Ariste and Valter Niilus to Latgale in 1936 focusing his work on Lielie Tjapši village in Pilda parish. Niilus worked primarily on Leivu and published a volume Valimik leivu murdetekste. Choix de textes dialectaux leivu. of Leivu texts with French translations and other information on Leivu (Niilus 1937). Sang wrote several unpublished studies ${ }^{4}$ on Lutsi phonology and noun and verb

4 Sang's original studies are stored at AEDFUL: phonology study (AES0193), noun study (AES0188), verb study (AES0189). Later handwritten copies of his studies are also available at AEDKL: phonology study (indexed as two separate documents - H0060, H0061), noun study (M0030), and verb study (M0029). 
morphology (Sang 1936b, 1936c, 1936d) and also kept a field journal (Sang 1936e) - stored at the Estonian National Museum - detailing his impressions of the Lutsis and his experiences during his 1936 expedition. Sang also wrote two additional records ${ }^{5}$ describing his work: a research journal of his 1936 expedition giving information on Lutsi consultants, communities, and the progress of his work (Sang 1936f), and a brief overview of his Lutsi research in 1937 (Sang 1937). Ariste also left a journal entry of his own dated 14 July 1936 describing some aspects of this expedition as well as noteworthy features of Lutsi (Ariste 1936). Sang took a large number of photos during his expedition, which are stored at the Estonian National Museum, and he and Ariste made the only known recordings of Lutsi from before the Second World War. These recordings ${ }^{6}$ made in 1938 - of Meikuls Jarošenko from Lielie Tjapši - are stored in the Archive of Estonian Dialects and Finno-Ugric Languages at the Institute of the Estonian Language (AEDFUL). Sang gives the following assessment of the Lutsi language situation about a decade after the one provided by Voolaine above:

\begin{abstract}
"Roughly estimating, I thought that the number of language speakers now stands at two hundred...First of all, it is difficult to draw a line between a speaker and a non-speaker. So, in "Uus Eesti" from 21 June 1936, the number of speakers - four hundred - seems correct if including those who know only a few greetings or curses in the language. And the above number - two hundred - would decrease five or six times if only those with mother language proficiency are considered proficient in the language." (Sang 1936a: 401)
\end{abstract}

Other documentation during the mid to late 20th century was carried out by linguists from Estonia including Salme Nigol and Salme Tanning. The audio recordings made are all from Lielie Tjapši and Škirpāni villages in Pilda parish and transcripts of many of these recordings were published in 2014 in the Estonian dialect text volume on the South Estonian language islands Eesti murded IX. Another important expedition undertaken by Latvian researchers - the 26th Folklorists' Expedition of the Latvian Academy of Sciences to Ludza District - in 1972,

\footnotetext{
5 Both journals are stored at AEDFUL. The 1936 journal is indexed as ESP0233; the 1937 journal is indexed as ESP0254.

6 The recordings are indexed as: EMH4088-03, EMH4090-02.
} 
documented folk songs but also traditions and other memories of the last Lutsi speakers and partial speakers in Pilda and Nirza parishes (for more on this expedition see Korjus 2021).

In the 21 st century, work has continued to document the memories and fragmentary language knowledge among Lutsi descendants. Hannes Korjus conducted a survey of Estonians living in Ludza District (Latvian: Ludzas rajons) (Korjus 2001) and in subsequent years has published a collection of Lutsi stories in Latvian which also included informational articles on the history of the community (Korjus 2003), other articles and books in Estonian (e.g., Korjus 2004, 2005, 2011), and more recently an in-depth study of Lutsi history (Korjuss 2017). Korjus (2002) describes the Lutsi language situation at the turn of the 21st century as follows:

"According to the Republic of Latvia Ministry of the Interior Population Register, on 1 January 2001, there were 17 residents of Estonian ethnicity living in Ludza District. Of the surveyed respondents, only two spoke Estonian, the rest communicated in Latvian and Russian or only in Russian. Estonian was not used as a family language by any family." (Korjus 2002)

As noted above, I began my work with Lutsi in 2013 and documented the language and memories of the last partial speaker and rememberers of Lutsi (for more see Sections 6 and 7, also Balodis 2019). In 2017, I also documented the current state of all 53 villages mentioned by Kallas, and in 2020, I published a Lutsi language primer (Balodis 2020) aimed at acquainting Lutsi descendants as well as Latvians in general with the Lutsi language and the history of the Lutsi communities using a Lutsi practical orthography I designed (described in Balodis 2015, 2020).

\section{Last speakers}

This section places some of the facts about changes in Lutsi language use, proficiency, and speaker number discussed above in the context of the last family where Lutsi was spoken - the Nikonovs-JarošenkoGermovs family of Lielie Tjapši village in Pilda parish. The story of how Lutsi knowledge changed from generation to generation in this 
family also reflects the change of language use in the Lutsi community. The story of these speakers is told through the memories of the researchers who interacted with them and their language proficiency is gauged using the Campbell and Muntzel (1989: 181) scale described at the beginning of this article. The quotes from these researchers given in this section are translated by me from Estonian (Sang) and Latvian (Pence, Vaba, Korjus).

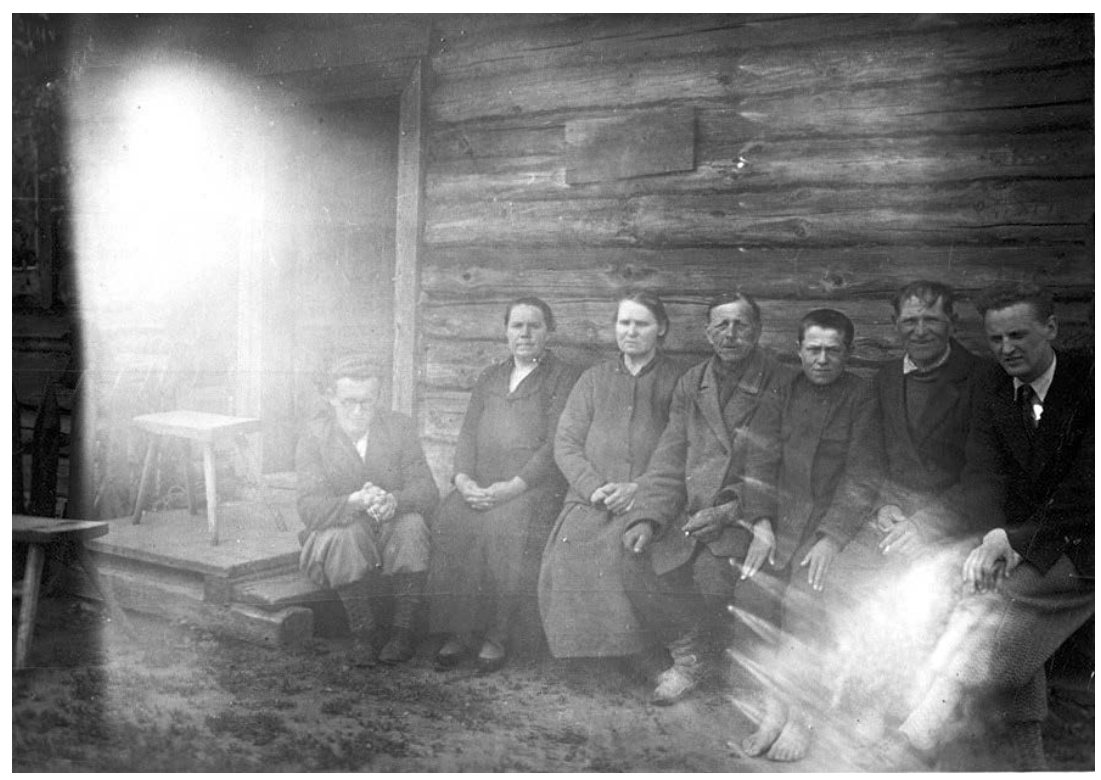

Figure 2. August Sang (left) and Paul Ariste (right) with the Jarošenko family. Tekla and Meikuls Jarošenko are third and fourth from the left. (Photo: Valter Niilus, 1936, Lielie Tjapši, Pilda parish, ERM Fk 754:114).

Tekla Jarošenko (née Germova; 1867-1962 or 1963) and Meikuls Jarošenko (1866-1945) - wife and husband - were S (strong) speakers of Lutsi and, as described in Section 5, were language consultants for linguists during Latvia's interwar independence. Their lives began decades before Kallas's 1893 expedition and even during Sang's documentation in the late 1930s, as shown by the quote below, several generations of their family and also members of their community used Lutsi as a language of interaction. A translation of an excerpt from an entry on 3 June 1936 in Sang's field diary describes the Jarošenko family and their Lutsi language abilities: 
"We are travelling with mag. [Paul] Ariste and stud. phil. [Valter] Niilus to Ludza. We first stop in Lielie Tjapši at Meikul Jarošenko's house. Meikul is a true Estonian man. His wife [Tekla Jarošenko], daughter [Antonina Nikonova], and grandson speak the dialect freely, [his] sonin-law - with difficulty. We are treated kindly, after eating we go $5 \mathrm{~km}$ on foot to the Raipole ${ }^{7}$ ksjonds (Catholic priest) who lives there...In the evening at the Jarošenko household, a group of local people have assembled - [they are] language speakers. The language is foreign, but understandable, though at first one lacks the experience and courage to dare [to attempt] a longer conversation." (Sang 1936e: 2-3)

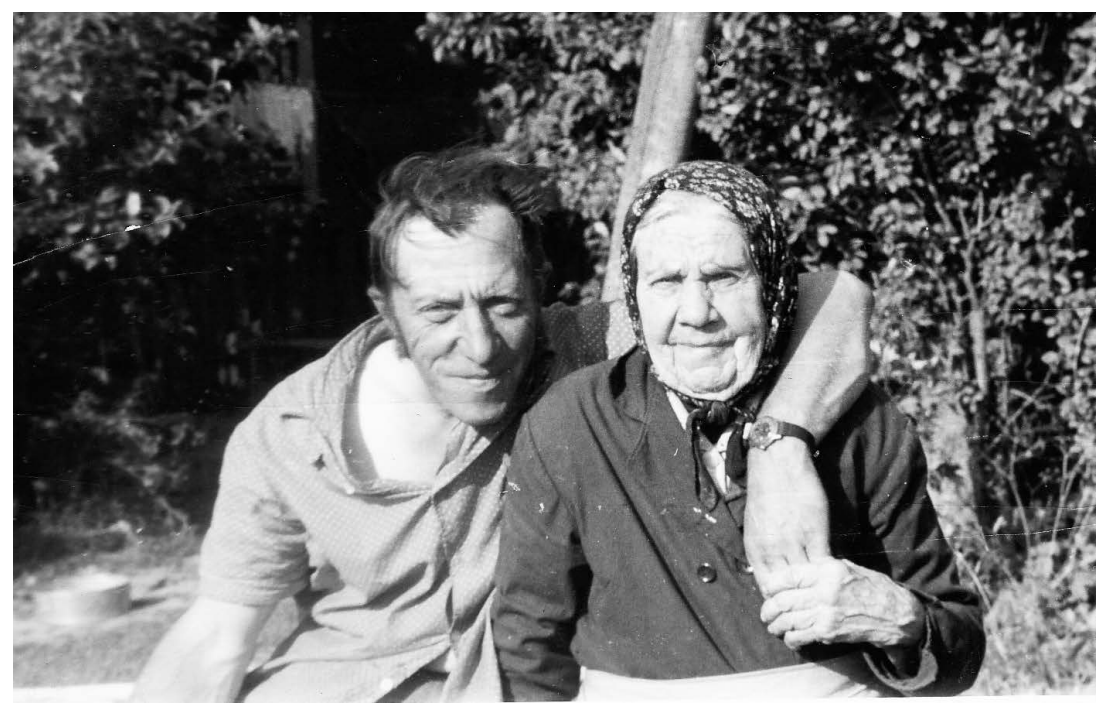

Figure 3. Nikolajs Nikonovs and his grandmother Antonina Nikonova. (Source: Nikonovs family photo album).

Antonina Nikonova ${ }^{8}$ (née Jarošenko; 1898-1983), daughter of Tekla and Meikuls Jarošenko, was also a strong speaker of Lutsi and served as a language consultant for linguists. Field recordings of Nikonova from the 1970s are stored at the Archive of Estonian Dialects and FinnoUgric Languages at the Institute of the Estonian Language (AEDFUL)

7 St. John the Baptist Roman Catholic church in Raipole has historically been of central importance to the Lutsis of Pilda parish.

8 Various spellings are used by different researchers for the names of Antonina Nikonova and her grandson's wife Antonina Nikonova. The spellings I use are those used on the headstones for both women in the cemetery adjoining Raipole church. 
and the University of Tartu Archive of Estonian Dialects and Kindred Languages (AEDKL). Nikonova was born only a few years after Kallas's expedition and during her youth Lutsi was still known in a handful of villages in Pilda and Nirza parishes. This situation would change throughout her life as the Lutsi-speaking area contracted to encompass only Škirpāni and Lielie Tjapši villages in Pilda parish by the 1970s and then, finally, only her native Lielie Tjapši village. Nikonova maintained her high proficiency in Lutsi throughout her life and passed on this knowledge to her son and grandson as well as fragmentary knowledge to her great-granddaughter. Her language knowledge and that of her parents and descendants is described in this translation from the field notes of Guna Pence from the 26th Folklorists' Expedition of the Latvian Academy of Sciences to Ludza District (For more on this expedition and Lutsi language attitudes at that time, see Korjus 2021).

"The consultant has lived in Tjapši for her whole life. Also her parents. Currently, Antonina N̦ikanova lives alone, is happy and able. She is often visited by her grandson Nikolajs and his wife who live nearby. N,ikanova's son Jezups lives in the city of Ludza. Antonina N,ikanova's father and mother (also husband) were Estonians. The consultant also has fluent knowledge of the Lutsi language; she taught it to her son and grandson. In addition, her son also learned the Standard Estonian language, as he studied in Estonia. In the past, N̦ikanova's home had been a gathering places for Lutsis: celebrations were held here, [also] meetings with linguists from Estonia. In practice, N,ikanova can be considered almost the only Lutsi who can speak the Lutsi language so fluently as well as the only one to have passed it down to the next generations. As a consultant, Antonnina N,ikanova is responsive, gladly sings Latvian as well as Estonian songs. The consultant participated in the concert at the Folklorists' 26th Research Expedition concluding conference where she sang in the Lutsi language. The materials collected during the expedition represent only a portion of that, which remains in the consultant's memory. Work with the consultant should be continued, especially with respect to collecting Estonian folklore. The consultant learned these songs from her parents and grandparents" (Pence 1972: 7-8).

Antonina Nikonova raised her grandson Nikolajs Nikonovs (19442006), though Nikonovs was not nearly as fluent as his grandmother and could be classified as being in between an I (imperfect) and W (weak) 
speaker, but closer to a $\mathrm{W}$ (weak) speaker, he was in a unique position to still have been exposed to spoken Lutsi in his earlier life, which is something that was no longer possible for later generations. There exist several field recordings ${ }^{9}$ of Nikonovs made in 1989, in which Nikonovs responds to the interviewing linguists' questions in Russian and to some extent in Lutsi.

Lembit Vaba (p.c.), who was one of the linguists who made these recordings, recounted his memory of Nikolajs Nikonovs' language abilities as follows:

"In the summer of 1989, dialect researcher Salme Nigol and I visited Nikolajs Nikanovs at his and his wife's home. For most of our visit, Nikolajs was lying in bed. He appeared physically very weak and sickly, but still was happy to speak with us. The dialogue was not lively, but $\mathrm{N}$ [ikolajs] remembered instructions and advice said in Lutsi, but no longer understood their meaning. Nikolajs had heard these from his grandmother Antonina, who had raised him, and he also confirmed this himself. “

Hannes Korjus (p.c.) who met Nikolajs in 2001, remembered Nikonovs' Lutsi language abilities as follows:

"Nikolajs knew individual words [in Lutsi] (including, profanities), place names, but I spoke with him in Latvian/Russian. Nikolajs tended to speak in Latvian-Latgalian, and so it was sometimes hard to understand him...He said that his grandmother Antonina had spoken the Lutsi dialect...[Nikolajs had grown up with] Antonina [who had raised him] instead of his mother."

Though I never met Nikolajs, I did meet his wife Antonina Nikonova (née Strumpe; 1949-2014). She remembered Nikolajs and his grandmother Antonina using some Lutsi with each other. Though Nikolajs' had less Lutsi ability than his grandmother, judging from the field recordings, he still had some ability to come up with short sentences in Lutsi.

9 The recordings are stored at AEDFUL and are indexed as: EMH4153, EMH4154, EMH4155, EMH4156. 


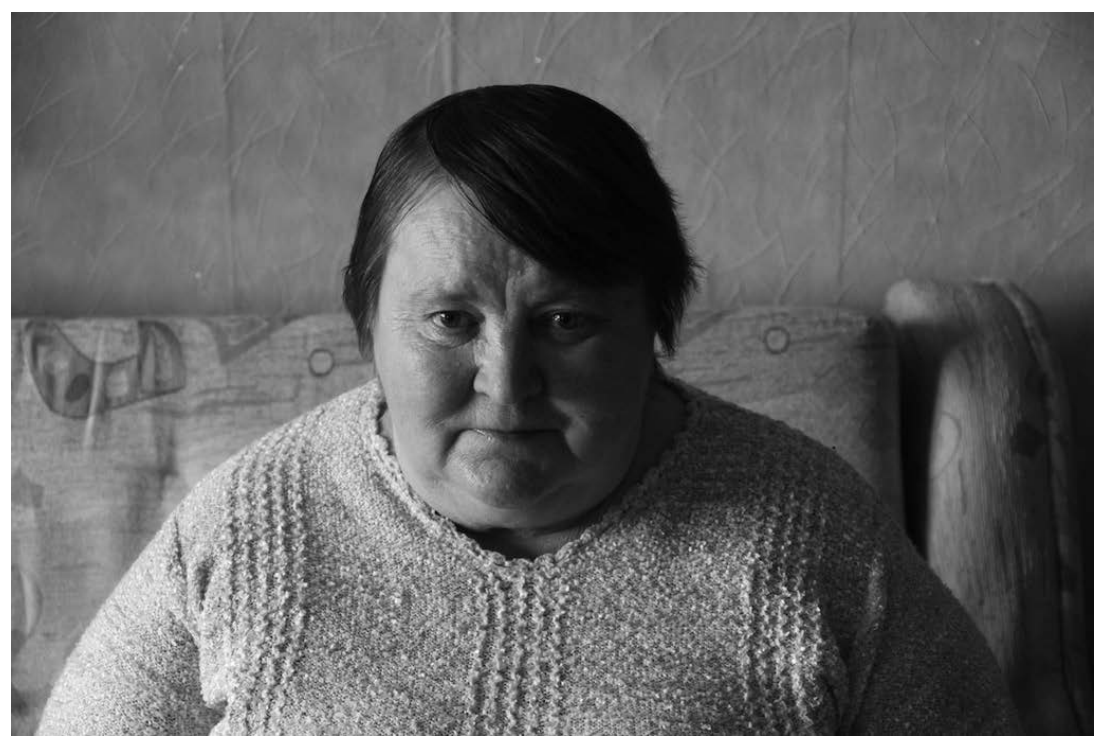

Figure 4. Antoņina Nikonova in her home in Pilda. (Photo: Uldis Balodis, 2013).

I met Antonina Nikonova and interviewed her on several occasions between 2012 and 2014. Unlike her husband, Anton,ina Nikonova was not able to make up simple sentences, but did remember words for different animals (e.g., kikas 'rooster', lihm 'cow') and even short phrases (e.g., ma sinnu salli 'I love you'). She also recalled some of the words and phrases she remembered her husband and his grandmother saying to each other (e.g., valge 'sugar [lit. white]'). Thus, Antonina Nikonova could probably be classified as being between a W (weak) speaker and a rememberer, as she did have a relatively large amount of Lutsi knowledge compared to other rememberers but did not seem to be able to construct sentences of her own.

Antonina Nikonova also appears in the documentary film Kadunud hõim: Lugu Lutsi maarahvast (Lost Tribe: A Story about the Lutsi Estonians) (Jääts \& Selgmäe 2014). In this movie, she can also be heard speaking Lutsi. The rememberer Helēna Kravale discussed in Section 7.3 also appears in the film. 


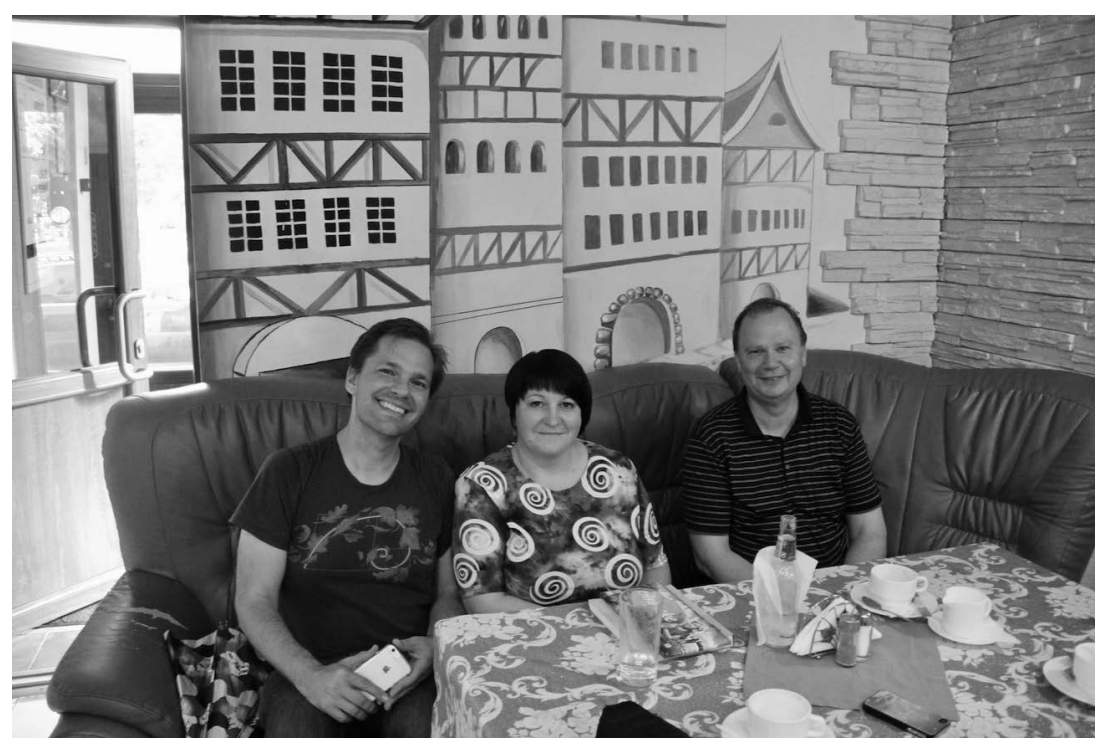

Figure 5. Anna Leščinska (centre) with Uldis Balodis (left) and Karl Pajusalu (right). (Photo: Renate Pajusalu, 2018, Ludza).

Some Lutsi language knowledge has been passed down in this family for at least one more generation. Anna Leščinska (née Nikonova; 1973), daughter of Antonina and Nikolajs Nikonovs, spent considerable time with her great-grandmother Antonina Nikonova in her childhood and remembered asking her great-grandmother to teach her to speak some Lutsi. When I met with Anna in 2018, she remembered the Lutsi greeting tere and also how to count from one to ten in Lutsi. At present, Leščinska is one of a handful of Lutsi rememberers in the community of Lutsi descendants, several of whom are described in Section 7.

\section{Rememberers}

At present, the only language knowledge remaining among Lutsi descendants is in the form of individual words and short remembered sentences. In this section, I describe the knowledge of three rememberers who remember more unique language fragments as well as the history of the Lutsi language in their own families and the source from which they learned what they remember. All of the quotes from rememberers given in this section are translated by me from Latvian. 


\subsection{Broṇislava Zambere}

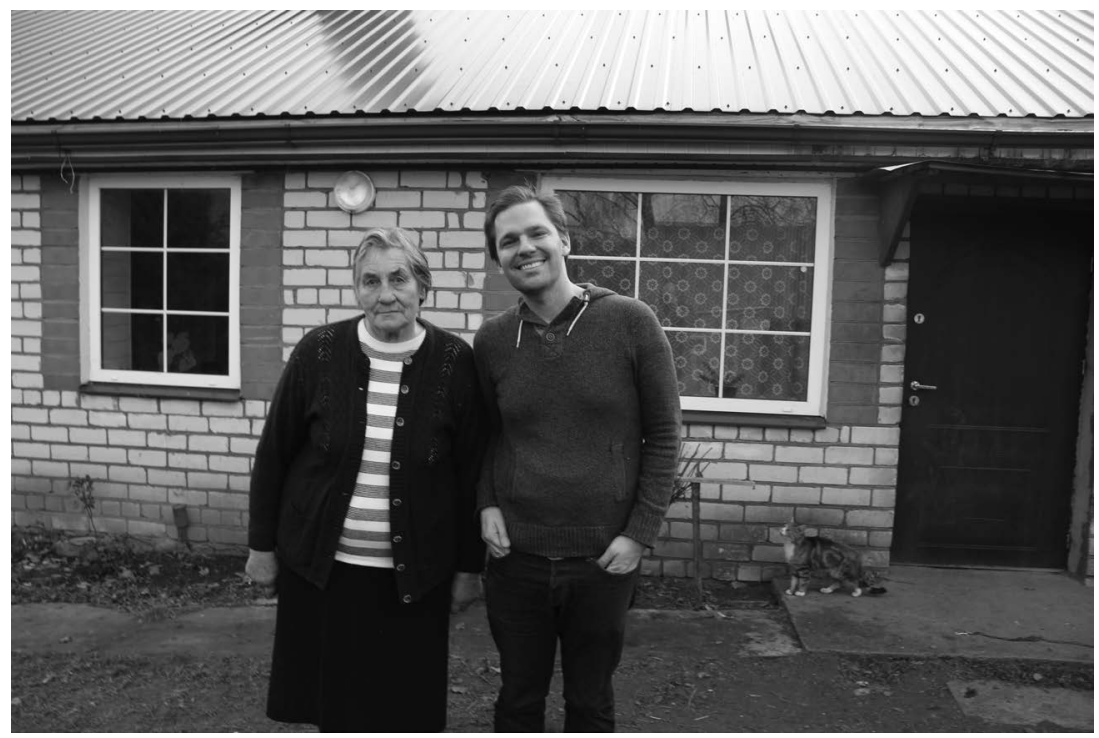

Figure 6. Bronislava Zambere and Uldis Balodis outside of Zambere's home (2014, Barisi).

I learned about Broṇislava Zambere (née Bule; 1938) thanks to a research study Igauñi Ciblas novadā (The Estonians of Cibla municipality) conducted by Ginta Birska (2009), a high school student at the time, in 2009, on the family histories of the Estonians of Cibla municipality.

I first met Zambere in 2014; she is the only Lutsi descendant whom I have met who clearly identified herself as Estonian. She told me "I'm Estonian. I'm proud of that." She also remembered visits by Estonians bringing gifts for the village children for Christmas during the Second World War and also Estonian researchers in the 1970s eating lunch at her house in Barisi. Of her ancestry and her family's language knowledge, she said:

"I remember my ancestors. My ancestors were real Estonians. My grandfather [Ignats Buḷs; 1859-1849] and grandmother [Cecelija Bule; 1865-1963] spoke Estonian, in Estonian, but not always... when they wanted the children not to understand, that's when they did. Father and mum, well, they understood something, but they didn't speak it." 
Birska includes a handwritten statement from Zambere in the back of her study in which Zambere writes out by hand the Lutsi numerals and story fragments she remembers. Zambere also writes: "In early childhood, [my grandparents] told me stories in Latgalian as well as in Estonian. I remember a very short story in Estonian." When I met Zambere she remembered how to count from 1 to 10 in Lutsi, how to say "My name is Bronislava" (pronounced by her as: mini nimi on bropislava), and also the story fragment mentioned in Birska's study. Birska (2009: 27) notes Zambere has also taught this story to her grandchildren, though I have not met them to confirm this.

My IPA transcription of this fragment from the recording I made of Zambere is given below in (1) along with a morphological analysis of the fragment. The free translation is the same as that given by Zambere in Latgalian, but also matches the content of the fragment. The Latgalian translation of the fragment, with the same meaning in English as (1), is given by Zambere in Birska's (2009) study as: Dzeivoja raizi večina ar vecīti koza ar trejim dālim, gara, gara posoka soksim nu gola.

$\begin{array}{llllll}\text { (1) etskuna } & \text { ieli } & & \text { tieda: } & \text { paba:ga } & \text { kits kolme } \\ \text { once } & \text { live.3SG.PST } & \text { old_man } & \text { old_lady.COM } & \text { goat three.GEN } \\ \text { puja:ga? } & \text { pik pik } & \text { jutus } & \text { alustəm } & \text { otsəst } \\ \text { son.COM } & \text { long } & \text { long } & \text { story } & \text { start.1PL.PRES } & \text { end.EL }\end{array}$

'There once lived an old man with an old lady, a goat with three sons. [It's] a long, long story, let's start from the beginning (lit. end).'

The story fragment resembles stories recorded earlier by other Lutsi researchers. For example, the fairy tale "Kiriele-kariele" (Voolaine 19251926: 15, Mets et al. 2014: 267) recorded from Petruḷa Bule (born 1855) in neighbouring Ščastḷivi (Lutsi: Tati külä) village in Nirza parish by Paulopriit Voolaine in 1925, which contains the line déda bābaga, kitş kolme pujaga 'an old man with an old lady, a goat with three sons'. Similarly, songs 9 and 10 entitled "Pikk jutt" in Lutsi maarahvas contain versions of the rest of this fragment, e.g., pikk pikk jutus - las ma otsast alusta 'a long, long story - let me start from the beginning' (Song 10) (Kallas 1894: 82).

Zambere did not seem to possess any other Lutsi language knowledge. However, it is impressive how clear and relatively intact this fragment had remained over the decades. Zambere's Lutsi language 
knowledge came from her grandparents - somewhat analogously to Nikolajs Nikonovs who also inherited his language from his grandmother. It is also interesting to note that Zambere's grandparents were born in the mid-19th century and as such would have not only been alive during the time of Kallas's 1893 expedition, but would have already been $30+$ years old at the time (though neither of them is listed among Kallas's informants in Lutsi maarahvas) and lived during the same period as Meikuls and Tekla Jarošenko described in Section 6.

\subsection{Leontīne Antonova}

I learned about Leontīne Antonova (1924-2019) when her niece attended the 2018 Lutsi studies seminar in Ludza that summer and played a video of her aunt reciting a Lutsi fragment she remembered. She also revealed that her aunt appears in a photo taken by Paulopriit Voolaine in 1937, which they had seen when it was republished in Hannes Korjus's 2017 Lutsi history study Ludzas igauni. This photo is also reproduced in this section as Figure 7. Later that summer I met with Leontīne Antonova and her sister with whom she shared an apartment in Rīga. Antonova's sister did not remember any words or phrases in Lutsi.

In my conversation with her, Antonova described how she had lived in Greči (Lutsi: Grēki) in Nirza parish in her youth, worked in the town of Nirza for a time, but then ultimately moved to Ludza to attend the technical college there. Her specialty was accounting, economics, planning, and then she moved to Rìga from Ludza in 1950. She remembered Paulopriit Voolaine's visits to Greči in her childhood and the Estonian Christmas celebrations he would organise for the village children.

Antonova's father, Antons Buls Pētera dēls (1875?-1951), ${ }^{10}$ spoke some Lutsi, but did not speak it to her, though she thought that her grandfather Pēteris had spoken Lutsi well. She also did not remember Lutsi being much spoken in Greči in her childhood. She mainly remembered her father and a neighbour speaking Lutsi including when they did not want her or her sister to understand what they were saying. An excerpt of Antonova's description:

10 The birth year of Antonova's father is estimated based on her statement that he died in 1951 at the age of 76 . 
“Well, Estonian wasn't spoken at all... I'm saying it was only my father. Pēteris - I didn't know [his] father, that is, my grandfather. But my neighbour was Lida's father's brother...Francis. He wasn't married. He was also bored. He would often run over to our place, to my father. And, well, then he sometimes wanted to speak some Estonian. Then he and my father would chat a bit."

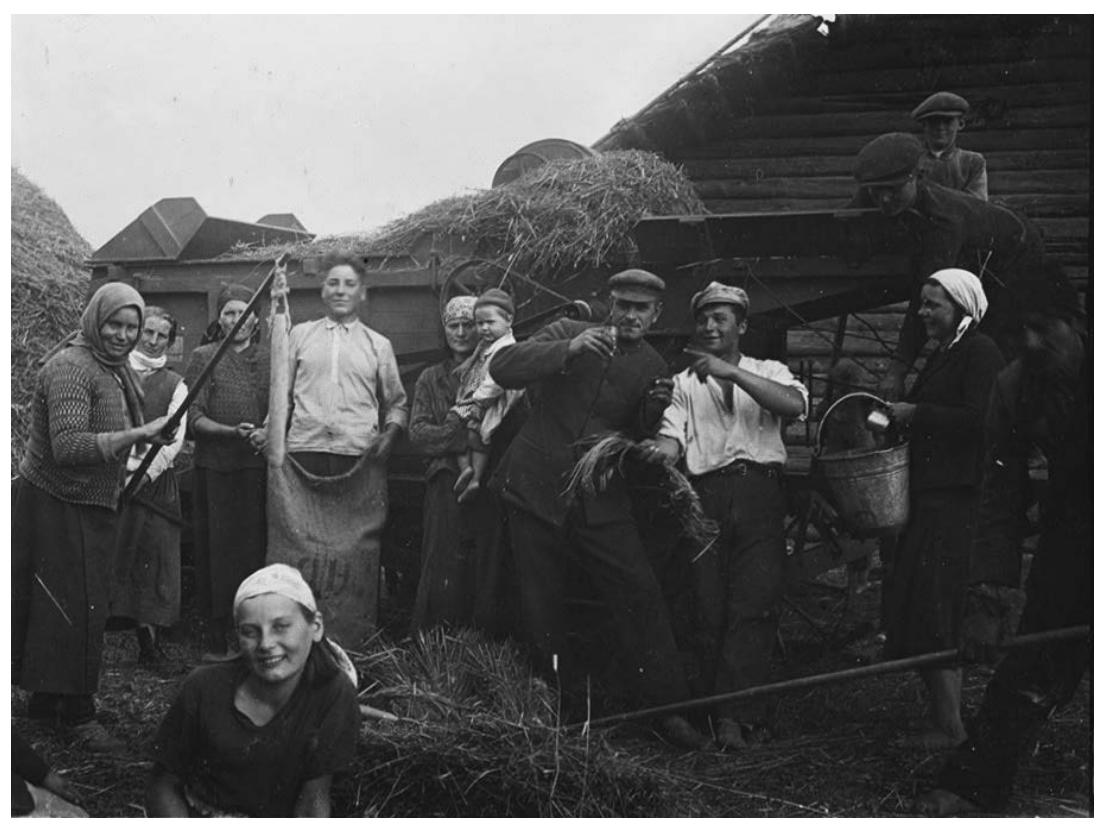

Figure 7. Leontīne Antonova (front left in a white kerchief), the woman who taught her the Lutsi song (right, also in a white kerchief), Antonova's mother Jezupata Bule (third from left), Antonova's father Antons Buls Pētera dēls (on the right, blurry). (Photo: P. Voolaine, 1937, at Antons Buls' home, Greči village, Nirza parish, ERM Fk 811:8).

Antonova learned her fragment from a neighbour Anna who also appears in Figure 7 on the right in a white kerchief. Antonova gives the following description: "I was taught [by]...Monika's sister [Anna]. I visited her in the evenings. She taught me a few things. She also taught me some poems in Latvian, one in Estonian."

The fragment Antonova remembered, shown in IPA in (2) with a morphological analysis and my proposed English translation, which is explained in the subsequent discussion, appears to combine elements 
Figure 8. Leontīne Antonova at her home in Rīga. (Photo: U. Balodis, 2018).

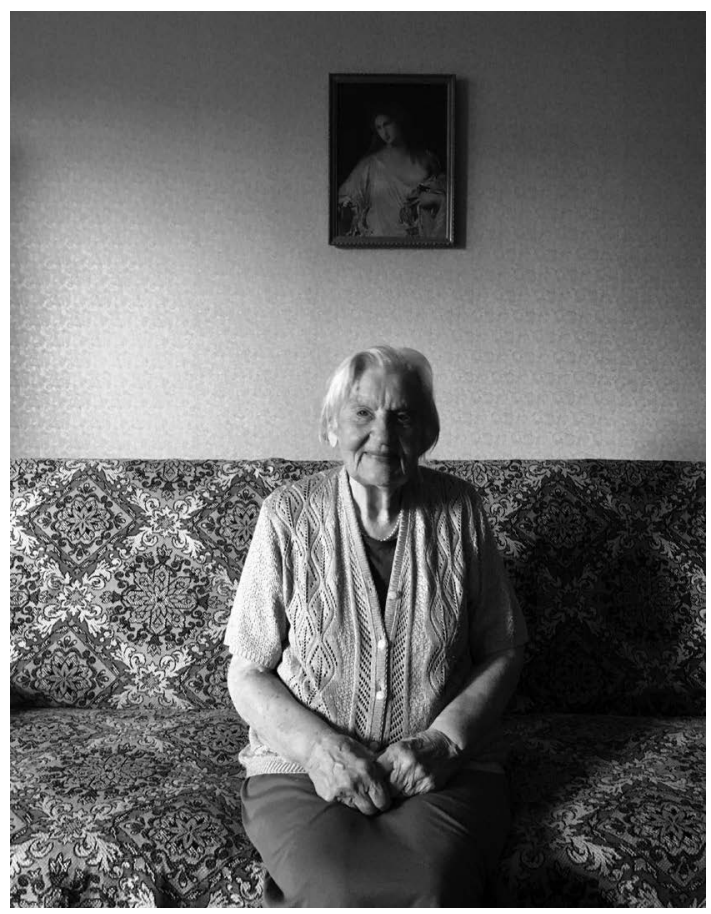

of two different Lutsi songs: "Kuzekene, kuzekene" and "Tsiri, tsiri, tsirgukene". Antonova herself remembered this fragment as meaning “Oh, little spruce, oh, little spruce, how lovely you are!" (The original wording given by Antonova in Latvian is: Ak, eglīte, ak, eglìte, cik skaista tu gan esi!), which is similar to the meaning of the first two lines of "Kuzekene, kuzekene" shown in (3), but does not fully translate the fragment in (2).

(2) ku:zikiji ku:zikiji little_spruce little_spruce
astu pesti kuivakini
oh_your ? little_dry_one
Oh, your... ?... little dry one.
varikini varba utsam In the forest, on top of a fencepost,
forest.IN fencepost.GEN top.IN
ku:lja ku:za otsan on top of a golden spruce.
gold.GEN spruce.GEN top.IN 
"Kuzekene, kuzekene" was written down by composer Emilis Melngailis in 1930 in Antonova's native village of Greči from Rozal̨a Bule (born 1845) and Petrula Bule (born 1865), and is shown in (3) in Melngailis's original spelling with an English translation. The source for this song is Melngailis's original handwritten transcription of it located at the Archives of Latvian Folklore at the University of Latvia Institute of Literature, Folklore, and Art (accessible at: http:/garamantas.lv/en/ unit/360754).

(3) Kuzekene, kuzekene, kalado, kalado, Little spruce, little spruce, kalado, kalado, A su ilu ilukisti, kalado, kalado! Oh your beautiful beauty, kalado, kalado!

Kündlikizi, kündlikizi, kalado, kalado, Little candle, little candle, kalado, kalado,

A su valu valukisti, kalado, kalado! Oh your luminous light, kalado, kalado!

With the exception of the refrain kalado, line 1 is the same as line 1 of Antonova's fragment and the first two words of line 2 a su are likely the same as $a s t u$ at the beginning of line 2 of Antonova's fragment in (2), while the final word kuivakini appears to be the diminutive kuivakine 'little dry one'. The middle word pesti is unclear and discussed separately below. It should be noted that the refrain kalado is also found in Latvian songs associated with mumming (kekatas) especially around Christmas but more generally between the Winter Solstice and Meteni (Ash Wednesday) (Jansons 2010: 59).

"Tsiri, tsiri, tsirgukene" is recorded as Song 36 in Kallas's language examples in Lutsi maarahvas, shown in (4) in Kallas's original spelling with an English translation. Compare also Song 35 - "Tsireline tsirgukõnõ", which includes the similar lines: Vaarikuna varba otsan, kuiva kuuze osa pääl. (Kallas 1894: 87); cf. also the last two lines of the Siberian Seto "Tsiri-tsiri, tsirgukõnõ": Varikuh varba pääl, kuiva kuusõ ossa pääl. (Source: http://www.folklore.ee/pubte/eraamat/siberilaulud/ setu/ee/02_14_laul.php)

The last two lines of Song 36 in (4) are very similar to those of Antonova's fragment, though Antonova uses the word ku:lja 'gold' instead of kuiva 'dry' in the last line of her fragment. It is also assumed that the word varikini from line 3 in (2) corresponds to the inessive form vaarikun 'in the forest' in line 4 in (4), rather than being a diminutive va(a)ri(ku)kine, as in this and other versions of this song (see Song 35 and the Siberian Seto song mentioned above), there is always an inessive form of $v a(a)$ rik 'forest' in this position. 
(4) Tsiri, tsiri, tsirgukene,

Para, para, pardzikene Kos sa kulda pezäkene! Vaarikun varba otsan, kuiva kuuze ladva otsan.
Tsiri, tsiri, little bird, Para, para, little duck, Where is your little gold nest? In the forest at the top of the fence post, at the top of a dry spruce.

The word pesti in line 2 of Antonova's fragment could be a phonetically reduced form of some other word or words, as the song recorded by Melngailis includes the words ilukisti and valukisti, the endings of which resemble pesti. It could also be connected with the word pezä 'nest', as its diminutive form pezäkene occurs in "Tsiri, tsiri, tsirgukene" in the line above those corresponding to the last two lines of Antonova's fragment. A third possibility, proposed in Balodis (2020: 151), is that this line in Antonova's fragment is Otsa pästä kuivikine 'dry from the head [i.e., top] of the treetop'.

The structure of Antonova's fragment is less clear than that of Zambere's in (1), because perhaps while Zambere's family did not speak Lutsi to her, her grandparents did tell her stories in Lutsi when she was a child. Thus, it may be that she was more frequently exposed not only to Lutsi in general, but to this fragment in particular, and so its phonology became more ingrained in her memory. From Antonova's description, Lutsi was only sometimes present in her home when her father and a neighbour would occasionally speak it to each other. She had to seek out this Lutsi fragment herself, asking a neighbour to teach her something in Lutsi. Presumably, she was exposed to Lutsi less often in her childhood and with less intensity, and her knowledge of this fragment was probably not reinforced over as long of a period of time - perhaps especially after she moved permanently to Riga in 1950 and with her father dying the following year. As a result, with time, its structure became less clear in her memory.

\subsection{Helēna Kravale and other rememberers}

There are other remembers too, mostly people that remember the greeting tere or a few numerals in Lutsi. An unexpected example of this took place in 2013 when I met Leontīne Bule who was 88 years old at the time and had lived and worked in Riga but would spend her summers at her family's home in L,ukati village (Lutsi: Lukodi), which itself 
was likely over a century old at the time, as, according to Bule, it had been moved to Lukati from Barisi in 1917.

According to Bule, the house was set to be demolished and a new one built in its place, but then this plan never came to pass as the Second World War arrived and so instead this old house remained standing where it did. I visited Lukati most recently in 2017 and at that time this house was still standing where it had for a full century since having been moved from Barisi. When I met Bule she still remembered the greeting tere, tere and this was a wonderful surprise, as I had not expected anyone in this village to remember even a single word of Lutsi, as no one, aside from Kallas in 1893, had documented any Lutsi language there.

One particular story of a single remembered Lutsi word bears repeating. I met Helēna Kravale (1925-2013) in 2013. Her grandparents Aleksandrs Mekšs (1854-1922) and Tekla Mekša (née L,ipovska) (1864-1946) - who lived in Vorkaḷi (Lutsi: Vārkali) village in Pilda parish - were the last to speak Lutsi. Tekla was Latgalian not Lutsi, but, according to Helēna, learned Lutsi after marrying Aleksandrs; Helēna said that Tekla and Aleksandrs would also use Lutsi as a way to speak in front of the children without them understanding.

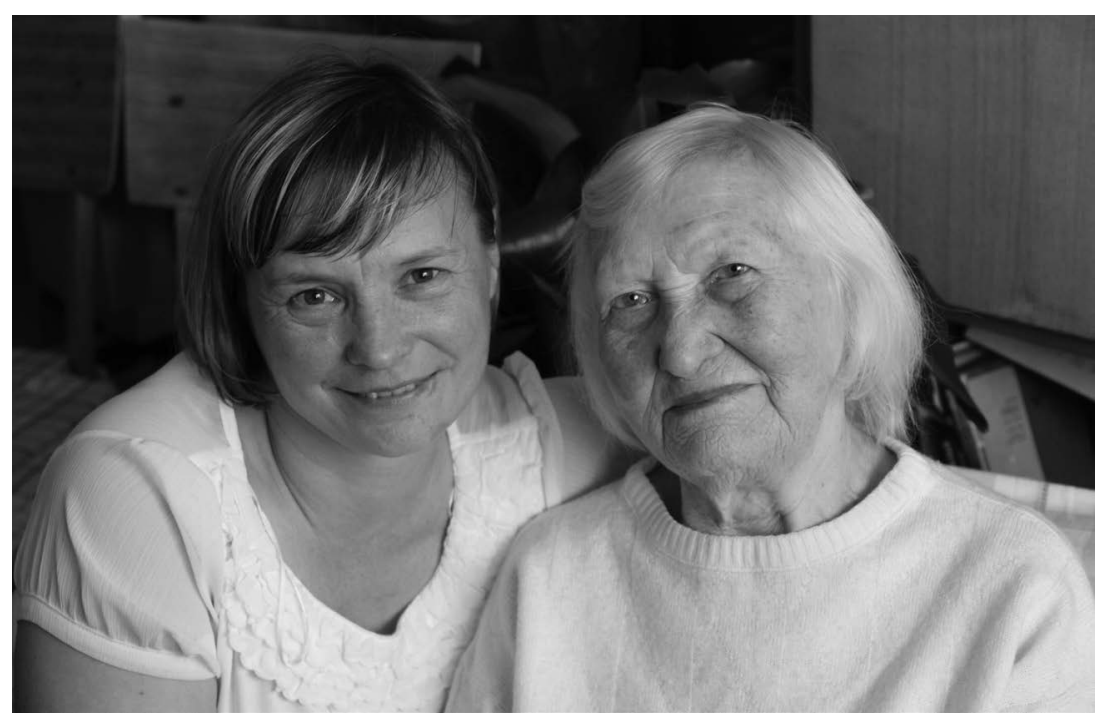

Figure 9. Helēna Kravale (right) with her niece Līga Kondrāte (left) in Helēna's apartment in Ludza. (Photo: U. Balodis, 2013). 
Little language documentation exists from Vorkalii. Kallas records one song (No. 101) from Vorkaḷi in Lutsi maarahvas, but does not give a name for the woman who sang it. Ojansuu lists a Lutsi language consultant from Vorkaḷi (Ul'ian Jāni poeg N'ukš) and writes that "there are very many [who] understand Estonian in Vorkalil" (Vaarkalissa hyvin paljon viron ymmärtäjiä.) on the first page of his Lutsi language notes dated 27 May 1911.

Helēna remembered a single word of Lutsi - suzi 'wolf' - because of a story that her mother Emīlija Kravale (née Mekša; 1897-1988) had told her. When Emîlija was a young girl, one day she had noticed a large grey dog following her as she walked home from school. When she got home and told her parents about this, she remembered them becoming very agitated and speaking to each other in Lutsi repeating the word suzi, as apparently it had not been a grey dog, but a wolf that had been following Emîlija on her way home from school.

Emīlija did not speak more than a few words of Lutsi according to her granddaughter Līga Kondrāte (née Kravale). However, this experience left enough of an impression on Emilija that she repeated this story and so memory of this single Lutsi word remained alive among her descendants up to the present.

\section{Remembered Lutsi and Finnic rememberers in Latvia}

As languages die, their systems experience change. Lutsi experienced gradual language death, ${ }^{11}$ as it was slowly replaced over several generations primarily by Latgalian, Latvian, and Russian. This section describes the characteristics of the last fragments of Lutsi and some of their shared features. It is beyond the scope of the current article, but a detailed study of all Lutsi language documentation showing how Lutsi transformed generation to generation as it underwent this process of change should be pursued in the future (for a discussion of grammatical

11 Campbell and Muntzel (1989: 182-186) discuss four types of language death: sudden death (a language dies suddenly due to the sudden death of its speakers), radical death (a language dies suddenly due to a severe external threat and speakers shift to a different language as a survival strategy), gradual death (a language dies over several generations as it is gradually replaced by a dominant language), bottom-to-top death (a language loses its colloquial registers and is used only in more formal situations). 
changes due to language death in Eastern Seto - a close relative of Lutsi - and other Finnic varieties, see Kehayov 2017). In this section, I also describe the fragments recorded from rememberers of Krevin Votic - the language spoken by another Finnic language island community in Latvia, as these are quite similar in character to those I found for Lutsi in the last years.

\subsection{The Characteristics of Remembered Lutsi}

Perhaps the feature, which the Lutsi fragments have most in common with each other is that for each there seemed to be a specific reason or event that led to it being remembered. For Bronislava Zambere, it was part of a story she heard in childhood. Also, perhaps its memory was associated with her sense of Estonian identity. For Leontīne Antonova, it was her own curiosity about Lutsi in her youth that led her to seek out a speaker to teach her how to say something in this language. This likely helped keep it alive in her memory throughout her life. And for Helēna Kravale, it was a story passed down from her mother connected with a particularly memorable event - her mother being followed home from school by a wolf. Even rememberers who recall just numerals or a greeting may have an emotional connection to this knowledge and have maintained it for this reason, e.g., Anna Leščinska who was very close with her great-grandmother Antonina Nikonova and asked her to teach her some Lutsi, as a result still knows a greeting and the numerals 1-10 in Lutsi.

I have made no attempt to draw generalisations here about the phonological character of these fragments, as they are too few in number and too short to be able to make such conclusions. However, some general observations can be made by comparing Bronislava Zambere's pronunciation of the Lutsi numerals $1-10$ with their approximate pronunciation in the first decades of the 20th century (based on pronunciations found for numerals in the Lutsi texts in Mets et al. 2014).

Table 2 compares these pronunciations. The left column shows the early 20th century Lutsi pronunciation and the middle column shows my IPA transcription of Bronislava Zambere's pronunciation. Note that in the original recording, Zambere speaks rather quickly, so these transcriptions are a best approximation of an imperfect recording of these numerals. In the recording, Zambere gives two different pronunciations 
for the numeral 'one' and it is unclear whether the numeral 'three' ends in $l, m$, or $l m$.

Zambere also recorded these numerals in her own hand in a written statement she wrote describing her Lutsi language knowledge found in the back of Birska 2009. Zambere uses a Latgalian-based orthography to write Lutsi where $<\mathrm{c}>$ is [ts], $<\mathrm{y}>$ represents an unrounded vowel, and long vowels are marked with a macron. Zambere's transcription is included in the right column, as it is interesting to see how she understands and hears her own pronunciation of Lutsi. Note that both in the recording and in Birska 2009, Zambere reverses the order of the numerals katieze 'eight' and etieze 'nine' (she writes the numerals in the following order: ic, kac, kol, nylie, vīs, kūs, sedzie, etieze, katieze, tjummie). In Table 2, these numerals are shown in their correct order.

Table 2. Comparison of early 20th century and B. Zambere's pronunciation of Lutsi numerals.

\begin{tabular}{|c|c|c|c|}
\hline Numeral & Lutsi & Zambere spoken & Zambere written \\
\hline 1 & $\mathrm{ytis}^{\mathrm{j}}$ & its, ets & ic \\
\hline 2 & kat $^{j} \mathbf{s}^{j}$ & kats & $\mathrm{kac}$ \\
\hline 3 & kol? & kol $\sim$ kom $\sim$ kolm & kol \\
\hline 4 & ne.li: & nr.li:(ə) & nylie \\
\hline 5 & $\mathrm{vi}:: \mathrm{s}^{\mathrm{j}}$ & vi:s & vīs \\
\hline 6 & $\mathrm{ku}: \mathrm{s}^{\mathrm{j}}$ & ku:s & kūs \\
\hline 7 & sæ:.dzje & se.dzi(ə) & sedzie \\
\hline 8 & ka.te:.za & ka.tiə.zə & katieze \\
\hline 9 & y.tje:.zæ & e.tiə.zə & etieze \\
\hline 10 & $\mathrm{k}^{\mathrm{j}} \mathrm{ym}^{\mathrm{j}} \cdot \mathrm{m}^{\mathrm{j} e}$ & tjym.me & tjummie \\
\hline
\end{tabular}

While every nuance of Zambere's pronunciation will not be analysed here, a few major themes emerge. In Latgalian, non-alveolar consonants are palatalised before front vowels and palatalised consonants can occur in every position (initial, medial, final) within a word (Nau 2011: 11). In Lutsi, every consonant - except $/ \mathrm{j} /$ and $/ \mathrm{R} /$ - can potentially be palatalised and consonants are palatalised before front vowels (Balodis 2020: 18). However, Zambere mostly does not pronounce palatalised consonants where they would be expected (based on the pronunciations 
shown in the left column). An exception is tymme 'ten', in which the initial consonant is palatalised before the front rounded vowel $y$. In some places, such as etizza 'nine' (historical pronunciation: $\left.y t^{j} e: z \propto\right)$ and possibly also in sedzi(a) 'seven' (historical pronunciation: $s a: d z^{j} e$ ) the palatalisation before the front vowel has been lost and the front vowel replaced by a diphthong $i$.

The front rounded vowel $y$ is replaced by either $i$ or $e$ in its, ets 'one' and etiaza 'nine', but is maintained in tiymme 'ten'. While both Lutsi and Latgalian have an unrounded vowel phoneme, this vowel does not occur in the original pronunciation of the Lutsi numerals 1-10; however, an unrounded vowel is found in Zambere's pronunciation of the numeral 'four' - nrli: (original pronunciation: neli:).

A phonetic contrast between long and short vowels is preserved in Zambere's pronunciation. Latgalian and Standard Latvian also have this same contrast. Certain differences between vowels are neutralised in Zambere's pronunciation and as a result final syllable vowels are generally pronounced by her as $\partial$. There is not enough material in the numerals or her remembered fragment from the Lutsi story to say clearly whether any residual features of vowel harmony remain in her pronunciation of Lutsi.

In terms of changes to the sound system, Campbell and Muntzel cite Andersen's (1982: 95) three hypotheses regarding the changes that languages undergo in language contact situations. Campbell and Muntzel (1989: 186) give these as:

“(1) the bilingual speaker of a threatened language (dying, for purposes of our discussion) will make fewer phonological distinctions in his or her use of the language than a fully competent (dominant or monolingual) speaker of the same language would. (2) However, he or she will preserve distinctions common to both his/her languages even while making fewer distinctions found only in the threatened language. (3) Distinctions with a functional load which is high (in terms of phonology and/or morphology) will survive longer in the speaker's use of his/her weaker language than distinctions which have a low functional load."

Zambere's pronunciation of the Lutsi numerals both supports and diverges from these hypotheses. In general, features found in Latgalian which is likely Zambere's dominant language, such as a vowel length 
contrast and an unrounded vowel, are preserved in her pronunciation of Lutsi. There is also a diminishing of contrasts between vowels seen in the general shift away from $y$ to $i$ or $e$ and the pronunciation of most final syllable vowels as $ə$. However, in at least one instance - in her pronunciation of the numeral 'ten' - the front rounded vowel $y$, which is not found in Latgalian at all, does seem to have been preserved. Likewise, the extensive palatalisation found in both Latgalian and Lutsi appears to be largely absent from Zambere's pronunciation of the Lutsi numerals.

As suggested above, a future study of the language of Lutsi rememberers should include a more precise acoustic analysis of these fragments and also place them in the context of the more fluent Lutsi recorded in the mid to late 20th century, in order to understand how Lutsi transformed in the last decades that it was actively spoken and whether the changes seen in 21 st century Lutsi already can be seen in this earlier more fluent Lutsi or if they are a more recent development. This study should also examine the features of the language of other rememberers. For example, in hearing Antonina Nikonova say ma sinnu salli 'I love you' and Helēna Kravale say suzi 'wolf', my impression was that in both of their pronunciations, $l l$ in salli and $z$ in suzi were pronounced as palatalised, which again would show another aspect of what features were preserved more generally in late Lutsi.

With respect to morphological and syntactic change, Campbell and Muntzel (1989: 191-195) provide examples of losses of morphological distinctions and syntactic change associated with language death. However, these are not entirely relevant to the Lutsi fragments discussed in this article. These fragments appear to be examples of rote memorised language, in which the morphological structure of words remains generally intact, perhaps because the rememberer recalls the fragment more as a series of sounds with a meaning attached to the entire fragment rather than it being produced word-by-word with insight into the meaning of each word and its structure. This would be akin to a person knowing set phrases - greetings, etc. - in other languages that they do not speak themselves (e.g., German auf Wiedersehen! 'see you later!', French bonne chance! 'good luck!', etc.) where the overall meaning of the phrase is understood, but the meaning of its components may not be.

This analysis is supported by my impression of listening to Zambere and Antonova deliver their remembered lines. While I never tried asking 
them what a specific word in the fragment meant, it felt that they had rote memorised them. Their recitation of their fragments was also accompanied by a kind of unique performative prosody. These seemed like phrases that they had said many times and that this prosody was a consequence of this. Perhaps this performative prosody even helped them remember their Lutsi fragments.

The fact that case endings appear quite intact especially in Zambere's fragment but also to some extent in Antonova's fragment, e.g., the comitatives paba:ga 'with an old lady', puja:ga? 'with a son', the elative otsast 'from the end' (in Zambere's fragment), and the inessive otsan 'at the end' (in Antonova's fragment), also may show that these fragments are rote memorised and therefore preserve the morphological structure of Lutsi rather well despite the rememberers likely having little or no insight into the meaning of each word in their fragment.

\subsection{Krevin Votic: Another example of Finnic rememberers in Latvia}

Finally, I wanted to connect the 21 st century language of Lutsi rememberers with that of another group of Finnic rememberers in Latvia dating to the 19th century - the Krevins. The Krevin community was a Votic language island, which spoke its variety of Votic for several hundred years in the vicinity of Bauska in southern Latvia until its assimilation into the surrounding population in the mid-19th century. Similarly to Lutsi, even after Krevin was no longer actively spoken, a few fragments were documented decades later from Krevin rememberers. These are extremely similar in character to the Lutsi fragments I found in the last years and are described by Winkler (1997: 117-118).

Ferdinand Johann Wiedemann recorded the first set of fragments several short sentences - in 1870 (published in Wiedemann 1871), which are similar in their scope and form to the Lutsi sentence remembered by Bronislava Zambere. Also, by coincidence, one of these Krevin sentences - suzi nessi lampe 'the wolf carried away a sheep' - contains the word suzi 'wolf', just as the Lutsi fragment recorded from Helēna Kravale.

The other fragment was recorded by Johannes Sehwers (Jānis Zēvers) in 1933 and consists of a short song fragment in Krevin with a Latvian translation provided by the consultant. Winkler quotes Sehwers' 
own assessment of this fragment, in which Sehwers (1940: 68) says that the man who gave him this Krevin fragment was not Krevin himself and had learned it years earlier from someone else. Sehwers also found the Krevin version of the song to be only partially intelligible. This is reminiscent of the situation with Leontine Antonova's remembered Lutsi song. Though she was of Lutsi descent, she did not grow up speaking Lutsi and learned her Lutsi song from someone else. Decades later when I was able to document it, the Lutsi version of the song was not entirely intelligible and the Latvian translation that Antonova provided at best corresponded only to the beginning of the song.

\section{Conclusion}

This article describes the last fragments - beyond greetings and numerals - remembered by members of the community of Lutsi descendants. It also paints a picture of how Lutsi was used and how its use changed over generations in Lutsi families as well as specifically in the Nikonovs-Jarošenko-Germovs family of Lielie Tjapši where spoken Lutsi persisted the longest.

Lutsi continued to be spoken in the Ludza area for at least several centuries and its documentation coincided with the century or so during which it passed from being a language used actively by speakers in Lutsi village communities to a language used in a handful of families in increasingly limited contexts and finally to the present day where only fragments are remembered by Lutsi descendants. While the specifics of the Lutsi language situation prior to Oskar Kallas's initial documentation of the Lutsis and their language in 1893 is unknowable, it seems that Lutsi must have been in a relatively stable situation in a part of Latvia, which historically has also been rather multilingual. (Recall Kallas's (1893: 17) observation of the Lutsi man who regularly used Lutsi, Latvian, Russian, and Polish depending on the context.) It may be that this multilingual situation was a factor in allowing Lutsi to survive for as long as it did. Speakers were accustomed to also knowing and using other languages, but knowledge of these languages did not prevent use of Lutsi in family and village community contexts. It may also be that the occasional addition of new speakers of South Estonian from Estonia - due to marriage or perhaps even migrations of larger groups 
of people - could have bolstered and periodically reinvigorated the use of South Estonian by the Lutsi community.

Comparing Ojansuu's observations of the Lutsi situation to those of Kallas (see Section 5), it is clear that language shift was already underway at the beginning of the 20th century. This process may have been further accelerated during Latvia's interwar independence when the role of Latvian - and to some extent Latgalian - was greatly expanded and its profile was raised. Additionally, a story I heard from several rememberers, which is also mentioned in this article (e.g., Helēna Kravale's memory of her grandparents' use of Lutsi), is that Lutsi-speaking parents and grandparents would use Lutsi with each other as a secret language to prevent children from understanding what they were saying. This certainly also impeded intergenerational transmission of Lutsi.

Section 8 of this article examines the shared features of the Lutsi fragments discussed in Section 7 and also compares them with the final fragments recorded from Krevin Votic rememberers in the 19th century. All of the Lutsi rememberers appeared to have a story or reason associated with their memory of their fragment. For some this remembered fragment may also be a source of pride or identity. While a comparative acoustic analysis of all remembered Lutsi fragments is beyond the scope of this article, the Lutsi numerals 1-10 recorded from rememberer Bronislava Zambere were compared to the pronunciation of these numerals as it would have been in the first decades of the 20th century. Zambere's pronunciation showed a decrease in vowel distinctions (the shift of the front rounded vowel $y$ to $i$ or $e$ in most cases and a shift of final syllable vowels to $ə$ in several cases) as well as a non-palatalised pronunciation of consonants where a palatalised pronunciation would be expected - a surprising change given the highly palatalised nature of not only Lutsi but also Latgalian, which is likely Zambere's dominant language.

Morphologically, the fragments remembered by Zambere and Antonova were largely intact, though, in my opinion, this is due to both rememberers having rote memorised their fragments as whole units rather than stretches of speech composed of discrete words where each word would be individually memorised and also understood separately from the entire fragment. No attempt was made to analyse the syntax of these fragments. 
A more detailed study of all of the phonological as well as morphological and syntactic features of these Lutsi fragments as well as Lutsi as it was spoken in earlier decades by more fluent speakers should be conducted in the future. Such a study would show how Lutsi changed over the decades and from generation to generation as the Lutsi community shifted increasingly to other languages. This could also show whether the characteristics observed in Bronislava Zambere's pronunciation of the Lutsi numerals are already present earlier or are limited only to her.

Today Lutsi is a dormant language. Though inherited knowledge of Lutsi is minimal, awareness of Lutsi roots and heritage is not uncommon among Lutsi descendants in the Ludza area. With the publication of the first Lutsi language primer last year (Balodis 2020) and increasing interest in Latvia and among the Lutsi descendant community in particular in Lutsi language heritage, knowledge of and about Lutsi is slowly expanding for the first time in decades. Whether reacquaintance of Lutsi descendants with their ancestral language will ever become a full language revival, still remains to be seen.

\section{Acknowledgments}

This study is supported by the National Research Programme project "Digital Resources for Humanities: Integration and Development" (VPP-IZM-DH-2020/1-0001; Latvia). Also, I would like to express my deepest appreciation to all speakers and rememberers for sharing their language knowledge with myself and the researchers who knew them. In addition, many thanks to Tuuli Tuisk for checking my IPA transcriptions of the Lutsi language fragments in Sections 7 and 8 and to the two anonymous reviewers for their insightful and helpful comments, suggestions, and recommendations.

\section{Archival sources}

AEDFUL $=$ Archive of Estonian Dialects and Finno-Ugric Languages at the Institute of the Estonian Language

(Estonian: Eesti Keele Instituudi eesti murrete ja soome-ugri keelte arhiiv, EMSUKA)

AEDKL $=$ University of Tartu Archives of Estonian Dialects and Kindred Languages (Estonian: Tartu Ülikooli eesti murrete ja sugulaskeelte arhiiv) 


\section{References}

Andersen, Roger W. 1982. Determining the linguistic attributes of language attrition. In R.D. Lambert \& B.F. Freed (eds.), The Loss of Language Skills, 83-118. Rowley, MA: Newbury House.

Ariste, Paul. 1936. Lutsi. Unpublished journal entry, July 14.

Balodis, Uldis. 2015. Writing down Lutsi: Creating an orthography for a South Estonian variety of Latgale. In Andra Kalnača (ed.), Valoda: Nozīme un forma 6, Valodas sistèma un lietojums. Language: Meaning and Form 6, Language System and Language Use, 55-67. Rīga: Latvijas Universitātes Akadēmiskais apgāds.

Balodis, Uldis. 2019. Expeditions among the Lutsi Estonians and the design of Language Learning Materials. In Sofia Björklöf and Santra Jantunen (eds.), Multilingual Finnic. Language contact and change. (Uralica Helsingiensia 14), 439-478. Helsinki: Suomalais-Ugrilainen Seura. https://doi.org/10.33341/uh.85046.

Balodis, Uldis. 2020. Lutsi kiele lementar. Ludzas igaunu valodas ābece Rīga \& Ludza: Latvijas Universitātes Lībiešu institūts, Ludzas pilsētas galvenā bibliotēka.

Balodis, Uldis. forthcoming. The distribution of inessive case endings in Lutsi. In Helle Metslang, Andra Kalnača, and Miina Norvik (eds.). Circum-Baltic languages: varieties, comparisons, and change (Potsdam Linguistic Investigations series). Potsdam: Peter Lang Publishing.

Birska, Ginta. 2009. Igauñi Ciblas novadā. Unpublished school paper.

Brandt, Adolph. 1845. Polnisch Livland und dessen Bewohner. Das Inland. 26-27.

Campbell, Lyle \& Martha Muntzel. 1989. The structural consequences of language death. In N. C. Dorian (ed.), Investigating obsolescence: Studies in language contraction and death, 181-196. Cambridge: Cambridge University Press. https://doi. org/10.1017/CBO9780511620997.016.

Iva, Sulev. 2007. Võru kirjakeele sõnamuutmissüsteem. (Dissertationes Philologiae Estonicae Universitatis Tartuensis 20). Tartu: Tartu Ülikooli Kirjastus.

Jansons, Jānis Alberts. 2010. Latviešu masku gājieni. Rīga: Zinātne.

Jääts, Indrek \& Maido Selgmäe. 2014. Kadunud hõim: Lugu Lutsi maarahvast. Lost Tribe: A Story about the Lutsi Estonians. Tallinn: Estonian National Museum.

Kallas, Oskar. 1894. Lutsi maarahvas. Helsinki: Suomalaisen Kirjallisuuden Seuran Kirjapaino.

Kallas, Oskar. 1903. Kraasna maarahvas. Helsinki: Soome Kirjanduse Seltsi Trükikoda.

Kehayov, Petar. 2017. The Fate of Mood and Modality in Language Death. Evidence from Minor Finnic. Berlin, Boston: De Gruyter Mouton. https://doi. org/10.1515/9783110524086.

Korjus, Hannes. 2001. Ludzas rajona igauñi 2001. gadā. Unpublished research study. Rīga: Latviešu folkloras krātuves arhīvs, LKF Nr. 2116.

Korjus, Hannes. 2021. From Sementovskij to the 20th century. Notes on the Lutsis in the Latvian press. Eesti ja soome-ugri keeleteaduse ajakiri. Journal of Estonian and Finno-Ugric Linguistics 12(2). 251-272. https://doi.org/10.12697/jeful.2021.12.2.10.

Korjuss, Hanness. 2002. Igauniskuma dimensija. Izglìtība un kultūra 12(2779), 7, 21 March. 
Korjuss, Hanness (ed.). 2003. Ludzas igauņu pasakas. Rēzekne: Latgales kultūras centra izdevniecība.

Korjus, Hannes. 2004. Lutsi maarahvas - 110 aastat hiljem. Fenno-Ugria Infoleht 1 (30). Available at: http://www.suri.ee/il/2004/1/lutsi.html (27 March, 2021).

Korjus, Hannes. 2005. Nirza valla lutsi maarahva päritoluga elanikud 2004. aastal. In Mari Mets \& Jüvä Sullõv (eds.), Tartu Ülikooli Lõuna-Eesti keele- ja kultuuriuuringute keskuse aastaraamat IV, 151-157. Tartu: Tartu Ülikooli Lõuna-Eesti keele- ja kultuuriuuringute keskus.

Korjus, Hannes. 2011. Lätimaal eestlasi otsimas. Tallinn: Kirjastus Kadmirell.

Korjuss, Hanness. 2017. Ludzas igauñi. Zemes dieva tauta. Rīga: Izdevniecība "Lauku avīze".

Manteuffel, Gustav. 1869. Polnisch Livland. Livländische Gouvernements-Zeitung. 126-144.

Mets, Mari, Anu Haak, Triin Iva, Grethe Juhkason, Mervi Kalmus, Miina Norvik, Karl Pajusalu, Pire Teras, Tuuli Tuisk \& Lembit Vaba. 2014. Lõunaeesti keelesaarte tekstid (Eesti murded IX). Tallinn: Eesti Keele Instituut, Tartu Ülikool.

Nau, Nicole, 2011. A short grammar of Latgalian. München: LINCOM Europa.

Niilus, Valter. 1937. Valimik leivu murdetekste. Choix de textes dialectaux leivu. Tartu: Akadeemilise Emakeele Seltsi Kirjastus.

Ojansuu, Heikki. 1912. Virolaiset siirtokunnat lättiläisalueella, niiden lähtöpaikka ja -aika. In Suomalainen Tiedeakademia. Esitelmät ja pöytäkirjat, 7-26.

Pajusalu, Karl. 2008. Lõunaeesti keel Lätis. In Péter Pomozi (ed.), Navigare humanum est... Pusztay Janos hatvanadik születésnapjara, 195-167. Budapest: Finnugor Népek Vilagkongresszusa Magyar Nemzeti Szervezete.

Pence, Guna. 1972. Latvijas Zinātņu Akadēmijas Valodas un literatūras institūta folklorist 26. zinātniskais ekspedīcijas dalībnieces G. Pences savāktie materiāli Ludzas rajonā 1972. gadā. Unpublished field notes. Latvijas folkloras krātuve, Nr. 2005. 985-1217.

Sang, August. 1936a. Lutsi maarahvas a. 1936. Eesti Kirjandus. 399-409.

Sang, August. 1936b. Morfoloogiline ülevaade (Noomen) Lutsi murdest. Unpublished research study. Tallinn: Archive of Estonian Dialects and Finno-Ugric Languages at the Institute of the Estonian Language. http://emsuka.eki.ee/view/book/283/0.

Sang, August. 1936c. Ülevaade Lutsi murde verbi morfoloogiast. Unpublished research study. Tallinn: Archive of Estonian Dialects and Finno-Ugric Languages at the Institute of the Estonian Language. http://emsuka.eki.ee/view/book/284/0.

Sang, August. 1936d. Lutsi murde häälikulooline ülevaade. Unpublished research study. Tartu: University of Tartu Archives of Estonian Dialects and Kindred Languages.

Part 1. https://murdearhiiv.ut.ee/naita.php?t=kasikiri\&id=1302

Part 2. https://murdearhiiv.ut.ee/naita.php?t=kasikiri\&id=1303

Sang, August. 1936e. Päevik etnograafiliste kirjelduste kohta Lutsis 1 juunist 20 juulini 1936 a. Unpublished field journal. Tartu: Estonian National Museum.

Sang, August. 1936f. Päevik murdeuurimisteekonna kohta Lutsimaale Pilda ja Nirza valda 1.VI-20.VII.1936. Unpublished field journal. Tallinn: Archive of Estonian Dialects and Finno-Ugric Languages at the Institute of the Estonian Language. http://emsuka.eki.ee/view/book/828/0. 
Sang, August. 1937. Lühike ülevaade murdekogumistöö käigust Lutsis 1937 a. suvel. Unpublished language documentation. Tallinn: Archive of Estonian Dialects and Finno-Ugric Languages at the Institute of the Estonian Language. http://emsuka. eki.ee/view/book/829/0.

Sehwers, Johannes. 1940. Die Kreewinen nebst einem Wörterverzeichnis der lettischen Lehnwörter in ihrer Sprache. Wörter und Sachen. Neue Folge III (Band 21). 65-77. Vaba, Lembit. 1997. Uurimusi läti-eesti keelesuhetest. Tallinn, Tampere: Eesti Keele Instituut, Tampereen Yliopiston suomen kielen ja yleisen kielitieteen laitos.

Voolaine, Paulopriit. 1925. Lutsi maarahvas 1925. a. Eesti Kirjandus. 372-379.

Voolaine, Paulopriit. 1925-1926. Fonograafilisi tekste Räpinast ja Lutsist. Unpublished language documentation. Tallinn: Archive of Estonian Dialects and Finno-Ugric Languages at the Institute of the Estonian Language. http://emsuka.eki.ee/view/ book/164/0.

Voolaine, Paulopriit. 1925-1927. Murdetekste Lutsist. Unpublished language documentation. Tallinn: Archive of Estonian Dialects and Finno-Ugric Languages at the Institute of the Estonian Language. http://emsuka.eki.ee/view/book/62/0.

Voolaine, Paulopriit. 1926a. Lutsi maarahva eestilisest liikumisest. Üliõpilasleht, 3, March 15, 37-40.

Voolaine, Paulopriit. 1926b. Noomeni ja verbi morfoloogiline ülevaade Lutsis. Unpublished research study. Tartu: University of Tartu Archives of Estonian Dialects and Kindred Languages. https://murdearhiiv.ut.ee/naita.php?t=kasikiri\&id=1715.

Voolaine, Paulopriit. 1927. Lutsi murde konsonantism ja vokalism. Unpublished research study. Tartu: University of Tartu Archives of Estonian Dialects and Kindred Languages. https://murdearhiiv.ut.ee/naita.php?t=kasikiri\&id=1262.

Weber, Tobias. 2021. A linguistic analysis of Heikki Ojansuu's phonograph recordings of Kraasna. Eesti ja soome-ugri keeleteaduse ajakiri. Journal of Estonian and FinnoUgric Linguistics 12(2). 343-390. https://doi.org/10.12697/jeful.2021.12.2.13.

Weske (Veske), Mihkel. 1877. Bericht über die Ergebnisse einer Reise durch das Estenland im Sommer 1875. Dorpat: Druk von H. Laakman.

Wiedemann, Ferdinand Johann. 1871. Über die Nationalität und die Sprache der jetzt ausgestorbenen Kreewinen in Kurland. Mémoires de l'Académie Impériale des Sciences de St.-Pétersbourg, VII ${ }^{\mathrm{E}}$ Série, Tome XVII, No. 2.

Winkler, Eberhard. 1997. Krewinisch. Zur Erschließung einer ausgestorbenen ostseefinischen Sprachform. Wiesbaden: Harrassowitz Verlag.

Kokkuvõte. Uldis Balodis: Lutsi keele kõnelejad ja mäletajad 20. ja 21. sajandi vahetusel. Lutsi keelt räägiti mitu sajandit Kagu-Lätis Ludza linna ümbritsevates valdades ja külades. Lutsi keel ja kultuur said tähtsaks osaks nii Latgali kui ka kogu Läti kultuuriajaloost. Lutsi keel on ühendanud Eestit ja Lätit ning saanud nende ühise pärandi sümboliks. Selle artikli esimeses osas kirjeldatakse lutsi keele uurijate (Oskar Kallas, Heikki Ojansuu, Paulopriit Voolaine, August Sang) mälestusi ja tähelepanekuid ajast, kui seda 
keelt veel räägiti igapäevaselt. Artikli teises osas antakse ülevaate Põlda valla Jaani küla Nikonovide perekonnast, kes olid viimaseid lutsi keele oskajaid. Samuti vaadeldakse viimaseid lutsi keelepärandi kandjaid tänapäeval - nn mäletajaid -, käsitledes nii nende elulugusid kui ka teadmisi lutsi keelest.

Kokkovyteq Lutsi kielehn. Uldis Balodis: Lutsi kiele kynelejaq ni mälehäjäq 20. ni 21. sā-āstaga vaihtusel. Mitu sā-āstakka kyneldi lutsi kīlt Ludzi ümbre valdohn ni küllihn. Lutsi kīḷ um nī Lätkalihn ku kaq kȳ Lätihn kultūri aolū tähtsä oza. Lutsi kīl um kaq tähtsä köüdüs Läti ni Ēstimā vaihel ni noide ütidze perändüze tunnismärḳ. Sjōl kirotuzel um katș ossa. Edimädzehn ozahn ma selledä lutsi kiele ūrjiide (Oskar Kallas, Heikki Ojansuu, Paulopriit Voolaine, August Sang) mälehüizi ni tähelepandmizi aost, ku tūd kīlt vīl egä päiv kyneldi. Tȳz̧ehn ozahn tī ülekaehuze Pylda valla Jāni külä Nikonovi perrest, kohn elliq perämädze lutsi kiele myistjaq. Ma ka kynele perämädzist Lutsi inemizist tämbädzel päväl - nm mälehäjidest -, kiä viḷ tīdväq veidüq lutsi kīlt, ni kaq noide elolūst ni kiele tīdmizest.

Märksõnad: ohustatud keeled, keelesaared, keelesurm, mäletajad, Latgale, läänemeresoome keeled, lõunaeesti, lutsi 